\title{
El forajido sentimental. Incursión por los escritos de Jorge Luis Borges
}

\author{
Sorrentino, Fernando \\ Editorial Losada. Argentina. 2011
}

\section{Introducción}

Ningún pueblo está regido por un tecnicismo estricto dentro de su lengua. Nadie, jamás en el mundo, se ha comunicado por la vía oral totalmente con un lenguaje puro y ortodoxo. El mundo habla como mejor se haga comprender, porque el idioma es algo vivo que se construye constantemente, no es algo estático, es viva transformación.

El idioma español en América está influenciado por el árabe, el latín, el griego, el hebreo, y por galicismos, italianismos, anglicismos y otras lenguas nativas. El lenguaje, a través de la historia del continente, se ha transformado en cada región. Por consecuencia, el español de cada país y dentro de los mismos mantiene sus propios códigos semiosféricos. Por lo mismo, en ocasiones es difícil la unificación del idioma español como vía oral entre los pueblos de Hispanoamérica. La forma más cercana de unificar el idioma es a través de la escritura.

El escribir conlleva, en sí mismo, la creación de un lenguaje y de realidades paralelas, la visión personal del mundo de quien está escribiendo. En estas realidades, el mismo escritor ingresa con distintos alteres para proveerle identidad a esos otros mundos, pero también convive con aquellos otros que es y con los mismos personajes que está creando o que está analizando como es en el caso del ensayo.

Fernando Sorrentino, en El forajido sentimental, realiza un ejercicio dialógico con su propia escritura y con las escrituras de otros autores. En este interjuego dialógico o dialéctico, también Sorrentino invita al lector a está apalabrada reunión. La manera, como él mismo lo dice, hedónica, de transmitir datos y llevarnos a través de su escritura por la historia, la literatura y las anécdotas nos mantienen como partícipes de lo que escribe:

El libro es este. Fiel a mis principios hedónicos, me conformaría con que el lector lo recorriera con un poco del placer que yo 
Reseña / El forajido sentimental. Incursión por los escritos de Jorge Luis Borges / Obed González Moreno

experimenté al redactarlo. (12)

Sorrentino nos va envolviendo para atarnos a una escritura, aunque en apariencia sencilla, inteligente en lo profundo, la sencillez es la manera más auténtica de comprender el mundo. A través de una dinámica amistosa, semejante a aquellas charlas bohemias donde datos, discusiones, lugares y nombres conviven con lo cotidiano nos adentra en su escritura. Esto es un acierto por parte del autor, que, percibo, es parte de su estilo. Esto que es la espontaneidad que ofrece la poética y diversifica el acto creativo.

\section{Estructura del libro}

El libro es un ensayo pero también un trabajo de investigación con toques biográficos que lo proveen de una profundidad porque el mismo Fernando, al escribir parte de la vida de Jorge Luis Borges, también nos está manifestando una parte de su vida con relación a Borges, es un cohabitar de esencias que alude a esta cuestión donde, en ocasiones, los escritores aman tanto a un personaje que este de cierta forma también dicta su vida a través de la mano del mismo escritor. Esta extraña simbiosis donde nos recreamos algunos:

Desde entonces, en una especie de enamoramiento eterno, continué leyendo y releyendo, una y otra vez, esas páginas que me ponían frente a una literatura única en el mundo, una literatura que no se parecía a ninguna otra que yo hubiera conocido, y que me proporcionaban lo único que mi abyecta frivolidad anhelaba (y sigue anhelando) hallar en los libros: el placer. De manera, digamos, "natural" comencé a redactar algunos artículos sobre distintos aspectos de la obra de Borges que surgían ante mí -sin que yo los hubiera buscado- en el mismo acto de la lectura. (11)

\section{El ejercicio narrativo dentro de El forajido sentimental}

El ejercicio narrativo en el libro es reflexivo, directo y ameno. La construcción de una obra es que esta, al ser concebida, sea parte del lenguaje del autor, aquello que proporciona identidad y pertenencia, y que no sólo se expresa a través de las letras, sino a través de proveerle pasión; armonía, coraje... vida. Es lo que logra Fernando Sorrentino en este libro.

$+308$


El libro está dividido en ocho capítulos donde el autor incursiona en una búsqueda de él y el mismo Borges. Nos introduce al texto con una explicación donde proporciona una visión sobre su incursión por los títulos del escritor bonarense, esta simbiosis de la que hablamos líneas atrás. A través de estos capítulos, nos muestra ese Borges pendenciero y en ocasiones espontáneo que algunos no desean aceptar, porque sería desmitificar al poeta, pero sí reafirma al hombre. Devela esas relaciones de Borges con otros y su actitud más allá de la escritura, su actitud ante los demás:

Por razones que ignoro, lo cierto es que la relación amistosa entre Borges y di Giovanni terminó por deteriorarse, y que el escritor argentino quedó resentido con su traductor norteamericano. (17)

Ese maestro que también era un humano y que, como cualquier persona, posee virtudes y defectos; Borges era muy agudo con su humor, podría decir que en algunos casos hasta perverso, pero lo que con más constancia manifestó fue una inteligente malicia:

- ¿Yo no le conté a usted lo que me pasó con di Giovanni? -comenta-. Bueno, él había traducido un libro mío al inglés. En uno de los relatos hay un indio que queda moribundo después de una batalla; se arrastra hasta el degollador y pide que lo terminen de matar. Dice así: "Mate, capitanejo Payé quiere morir". ¿Sabe qué puso di Giovanni, en una llamada que hizo al pie del libro?: "Mate: infusión criolla que se succiona con un adminículo llamado bombilla". A mí me parece asombroso que no se diera cuenta de que lo que pedía el indio era que lo mataran y no que le cebaran unos mates... No sé, era como si pidiera una cerveza Quilmes o una ginebra Bols. (18)

Analizando el libro, también podemos observar cómo Fernando, a través de algunos personajes y el mismo Borges, nos muestra parte de la cultura de Argentina, algunos gustos y nombres que nos sugieren una visita a aquel país, como es en mi caso, y que nos acompaña no nada más de eso, sino de la atmósfera que se va creando durante la explicación:

Borges y Alifano están conversando sobre el hábito de tomar mate, los errores que se cometen en su preparación, las ácidas consecuencias de una ingesta exagerada, etcétera. Ahora bien, el mate no solo es la infusión sino también el receptáculo en que se lo bebe. La estricta ortodoxia indica que este debe ser una calabaza; la heterodoxia puede adquirir diversas formas reprobables (un jarrito celeste, en el caso del don Isidro Parodi de los Seis 
Reseña / El forajido sentimental. Incursión por los escritos de Jorge Luis Borges / Obed González Moreno

problemas; un mate de madera, en el del autor de estas líneas; y hasta -horresco referens- un vasito de vidrio en los ejemplos más heréticos). (18)

Dentro del libro hay bastantes anécdotas de Borges y muchísimos nombres y lugares; esto enriquece la obra por la multiplicidad de voces que se cuelan en él y se transforman en un universo de conceptos y experiencias, para ejemplificar Sorrentino escribe una experiencia entre Alfonso Reyes y Borges, Reyes a quien Borges admiraba y consideraba un gran escritor; Fernando nos recrea esta situación en un subtítulo llamado La honradez mexicana y el honor argentino, donde nos muestra ese juego con el lenguaje del cual ambos eran expertos. No sólo nos habla de la admiración del maestro por Alfonso Reyes, sino también por obras como Martín Fierro que simboliza la tradición y raíces del pueblo argentino:

Una función del arte es legar un ilusorio ayer a la memoria de los hombres; de todas las historias que ha soñado la imaginación argentina, la de Fierro, la de Cruz y la de sus hijos es la más patética y firme. (66)

El forajido sentimental es un recorrido por Argentina a través de la pluma de Fernando Sorrentino pero dictada a través de su incursión por los escritos de Borges. Podría escribir más, mucho más con relación al libro, pero se perdería el lector de la riqueza del mismo y en ocasiones hay que repartir el pastel aunque sea a pequeños y delicados trozos para que quede, en quien ha sido dosificado, el deseo de poderlo devorar completo y a gusto.

\section{Conclusión}

A través del acto creativo, el poeta, que es un creador, va dialogando consigo mismo y con aquellos que ha leído con anterioridad, para apoyarse dentro de este gusto por la creatividad. Esta dinámica produce una cierta atmósfera que permite al escritor, en este caso, recrearse en las palabras de otros para mantener una comunicación que lo dirige a esa otredad, que es el mismo instante del ejercicio escritural, como lo manifiesta Fernando Sorrentino en El forajido sentimental.

Obed González Moreno

Museo Nacional de Arte (INBA)

$+210$

